Jurnal Ekonomi Pembangunan

Volume 11, Nomor 2, Desember 2010, hlm.191-201

\title{
PERTIMBANGAN, PENGETAHUAN, DAN SIKAP KONSUMEN INDIVIDU TERHADAP BANK SYARIAH
}

\author{
Wiwiek Rabiatul Adawiyah \\ Fakultas Ekonomi Universitas Jenderal Soedirman \\ Jalan HR. Boenyamin Nomor 708 Purwokerto, Jawa Tengah, Indonesia, Telepon +62 281635292
}

Diterima 20 September 2010/Disetujui 15 Oktober 2010

\begin{abstract}
This study aimed at finding out the selection criteria considered by individual customers in choosing Islamic (Syariah) banks; assessing the degree of customers knowledge on Islamic banks products; and finally to determine customers' attitudes towards Islamic banks. The sample of the study was individual customers of Bank Muamalat and Bank Syariah Mandiri located in Banyumas Regency. There were two steps employed in analyzing the data: descriptive and factor analysis. The result of the study shows that there are seven factors to be considered by customers in patronizing Islamic banks. Among those factors are: perception, process, tangible, price, people, social and location. The most important factor considered by customers is perception factor. Moreover, customers' knowledge on Islamic banks is still narrow, some do not even familiar with the products offered by Islamic banks. Religion is not the main reason for customer to patronize Islamic bank, other important reason is the level of profit sharing offered by the banks.
\end{abstract}

Keywords: selection criteria, knowledge, attitudes, consumers, Islamic banks

\begin{abstract}
Abstrak: Penelitian ini bertujuan menganalisis kriteria seleksi yang dipertimbangkan konsumen individu dalam memilih bank Syariah; mengetahui tingkat pengetahuan konsumen terhadap produk perbankan Syariah; serta menganalisis sikap konsumen terhadap bank Syariah. Subyek penelitian adalah konsumen individu yang menggunakan jasa Bank Muamalat Indonesia serta Bank Syariah Mandiri di Kabupaten Banyumas Purwokerto. Metode analisis data adalah deskriptif statistik dan analisis faktor. Hasil analisis menyimpulkan bahwa ada tujuh faktor yang dipertimbangkan konsumen dalam memilih bank Syariah antara lain: persepsi, proses, kondisi fisik, harga, sumber daya manusia, sosial dan faktor lokasi. Persepsi konsumen merupakan faktor yang paling berpengaruh terhadap keputusan konsumen dalam memilih bank Syariah. Sebagian responden memiliki keterbatasan pengetahuan tentang produk perbankan Syariah. Agama bukanlah alasan utama konsumen inidividu dalam memilih bank Syariah. Konsumen lebih mempertimbangkan laba atau bagi hasil yang ditawarkan bank Syariah dibanding faktor lainnya.
\end{abstract}

Kata kunci: kriteria seleksi, pengetahuan, sikap, konsumen, bank Syariah

\section{PENDAHULUAN}

Berdirinya Islamic Development Bank (IDB) telah memotivasi banyak Negara Islam untuk mendirikan lembaga keuangan syariah. Pada akhir periode 1970an dan awal dekade 1980an, bank syariah bermunculan di Mesir, Sudan, negaranegara Teluk, Pakistan, Iran, Malaysia, Bangla- desh, serta Turki (Antonio, 2001). Di Indonesia, perkembangan industri keuangan syariah secara informal telah dimulai sebelum dikeluarkannya kerangka hukum formal sebagai landasan operasional perbankan syariah, pada tahun 1992.

Perkembangan industri perbankan syariah saat ini telah menciptakan persaingan usaha 
antarbank syariah. Untuk memenangkan persaingan tersebut, Bank harus berkreasi dan berinovasi dalam mengetahui kebutuhan, keinginan, selera konsumen, perilaku beli mereka dan merancang produk untuk memenuhi kebutuhan tersebut secara lebih baik dari apa yang dilakukan kompetitor, serta mempengaruhi konsumen untuk membeli produknya berdasarkan perilaku mereka (Prasetijo et al, 2004).

Penelitian mengenai kriteria seleksi bank sudah banyak dilakukan oleh peneliti di dalam maupun luar negeri. Erol dan El-Bdour (1989) dianggap sebagai peneliti yang pertama kali meneliti tentang sikap konsumen terhadap bank syariah. Penelitian dengan menggunakan kuesioner untuk mengetahui sikap, perilaku dan faktor kriteria seleksi bank, baik bank syariah maupun konvensional di Jordania. Pada penelitian tersebut disimpulkan bahwa pelayanan cepat dan efisien, reputasi dan image bank, serta kredibilitas bank merupakan faktor utama dalam memilih bank, baik bank syariah maupun konvensional. Hasil yang sama juga didapat dari penelitian yang dilakukan oleh Erol et al. (1990), Haron et al. (1994), Hegazy (1995), serta Gerrard dan Cunningham (1997). Dalam penelitian-penelitian tersebut juga didapat bahwa pelayanan cepat dan efisien mempunyai nilai yang paling tinggi di antara faktorfaktor kriteria seleksi lainnya (Gait et al., 2007). Hal ini menunjukkan bahwa faktor agama bukanlah alasan utama bagi konsumen dalam memilih bank syariah.

Penelitian lain yang dilakukan oleh Omer (1992), Metwally (1996), Metawa dan Almossawi (1998), Al-Sultan (1999), serta Bley dan Kuehn (2004) mendapatkan hasil yang berbeda dengan hasil di atas. Pada penelitian-penelitian ini ditemukan bahwa sebagian besar responden memilih agama sebagai faktor utama yang memotivasi mereka dalam menggunakan produk dan jasa perbankan syariah (Gait et al., 2007). Hasil penelitian Bank Indonesia (2000) menunjukkan adanya potensi pasar yang cukup besar bagi bank syariah. Faktor yang menjadi alasan konsumen dalam memilih bank syariah di wilayah provinsi Jawa Barat, Jawa Tengah, dan Jawa Timur berbeda (Bank Indonesia, 2000). Untuk itu perlu dilakukan penelitian tentang persepsi konsumen, pengetahuan serta sikap konsumen di Kabupaten Banyumas, sebagai upaya untuk melengkapi rangkaian penelitian tentang bank Syariah di Indonesia.

\section{METODE PENELITIAN}

\section{Metode Penelitian dan Sampling}

Penelitian ini merupakan penelitian survey tentang kriteria seleksi, pengetahuan dan sikap konsumen terhadap bank syariah. Subjek penelitian ini adalah nasabah bank umum syariah di Purwokerto. Penelitian ini dilakukan di kota Purwokerto. Metode pengumpulan data dalam penelitian ini adalah kuesioner, yaitu dengan menggunakan daftar pertanyaan yang telah dipersiapkan untuk diisi oleh responden yang terpilih sebagai sampel.

Populasi dalam penelitian ini adalah nasabah Bank Muamalat Indonesia dan Bank Syariah Mandiri cabang Purwokerto. Karena penelitian ini menggunakan 24 variabel, maka sampel yang digunakan adalah sebanyak 120 sampel (24 x 5). Pengambilan sampel dilakukan dengan metode purposive sampling, yaitu teknik pengumpulan data dimana siapa yang akan dijadikan sampel diserahkan pada pertimbangan pengumpulan data yang menurut peneliti cocok dengan tujuan dari penelitian atau sendiri (Supranto, 1997). Pertimbangan sampel yang akan dipilih adalah nasabah bank syariah di Purwokerto yang masih aktif. Kriteria yang diambil adalah nasabah yang memiliki rekening tabungan dan pernah melakukan transaksi di bank syariah.

\section{Definisi Operasional Variabel}

(1) Faktor pertimbangan konsumen. Faktor-faktor yang menjadi pertimbangan konsumen individu ada 24 faktor, yakni pelayanan cepat; pelayanan efisien; kredibilitas bank; kredibilitas manajemen bank; luasnya jangkauan pelayanan; reputasi dan image bank; keramahan personel bank; penyediaan pelayanan konsultasi keuangan; biaya pinjaman yang rendah; istilah pembiayaan yang menarik; lokasi dekat tempat tinggal; biaya jasa yang rendah; bagi hasil yang tinggi; sambutan bank yang diberikan; hak istimewa (overdraft) bagi pemegang rekening; kenyamanan interior; pengiklanan di media 


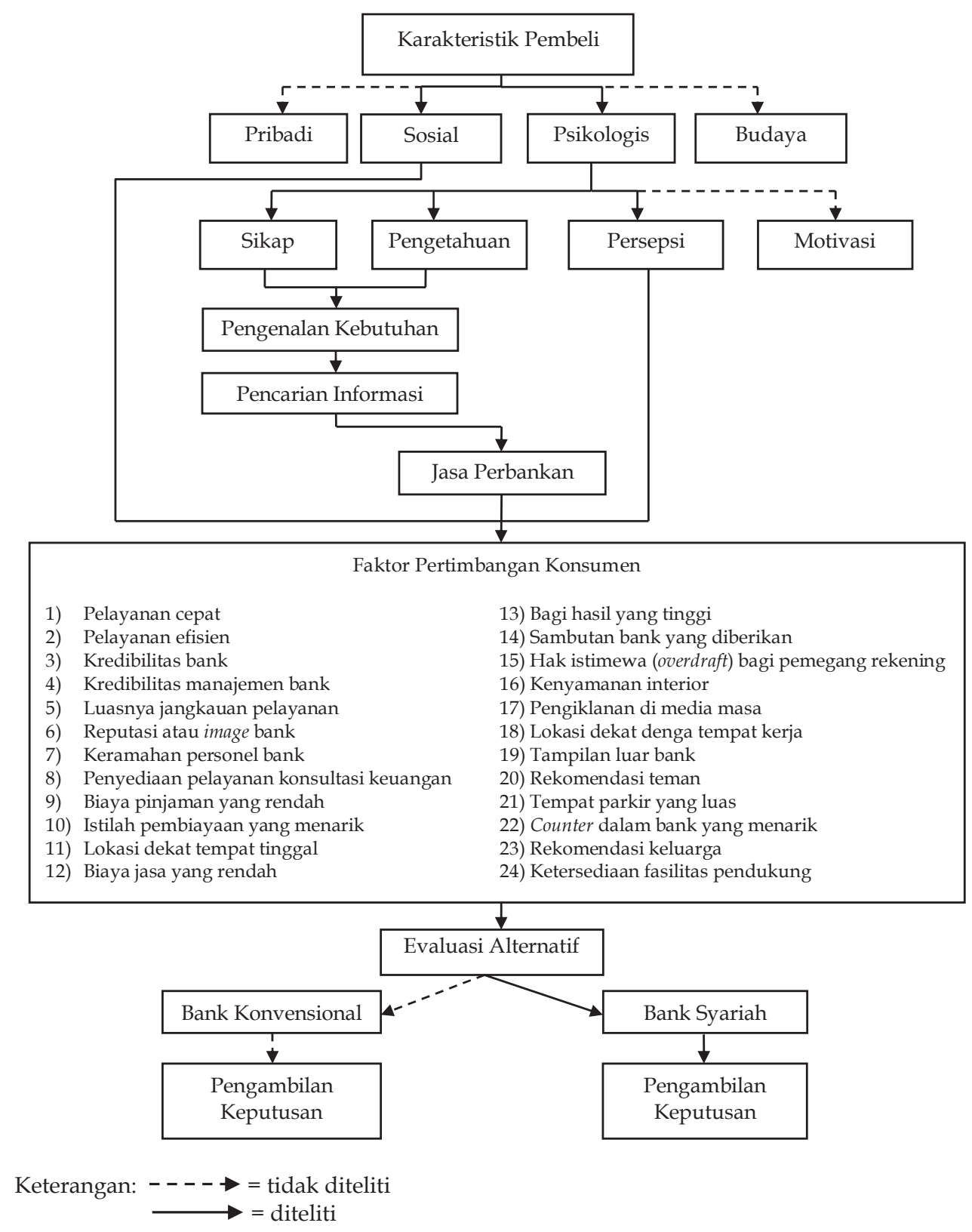

\section{Gambar 1. Kerangka Pemikiran Penelitian}

masa; lokasi dekat dengan tempat kerja; tampilan luar bank; rekomendasi teman; tempat parkir yang luas; counter dalam bank yang menarik; rekomendasi keluarga; dan ketersediaan fasilitas pendukung (Gerrard dan Cunningham, 1997).

(2) Pengetahuan. Pengetahuan konsumen adalah semua informasi yang dimiliki konsumen mengenai berbagai macam produk dan jasa (dalam hal ini produk dan jasa bank syariah), serta pengetahuan lainnya yang terkait dengan produk dan jasa tersebut dan informasi yang berhubungan dengan fungsinya sebagai konsumen (Sumarwan, 2004). Indikatornya adalah pengetahuan konsumen tentang: riba, syariah, ijarah, mudharabah, musyarakah dan murabahah.

(3) Sikap. Menurut Thurstone dan Fishbein, sikap mewakili perasaan senang atau tidak senang konsumen terhadap objek yang dipertanyakan (Setiadi, 2003). Indikatornya adalah: (a) 
alasan yang mendorong konsumen untuk menabung di bank syariah; (b) sikap konsumen apabila bank syariah membuka cabang yang tersebar di seluruh negeri; (c) sikap konsumen apabila diumumkan bahwa menabung di bank syariah tidak akan mendapatkan laba; (d) sikap konsumen terhadap bank syariah yang meminjamkan modal tanpa bunga sebagai suatu kontribusi pihak bank dalam membatu masyarakat; (e) sikap konsumen apabila mendapatkan uang yang tidak terduga; dan (f) sikap konsumen tentang penghapusan tingkat bunga pada pinjaman pada prinsip bagi hasil di bank syariah.

\section{Analisis Deskriptif}

Analisis deskriptif mengacu pada transformasi dari data-data mentah ke dalam suatu bentuk yang mudah dimengerti dan diterjemahkan. Pendeskripsian respons atau hasil observasi merupakan ciri khas dari bentuk pertama analisis. Perhitungan rata-rata, distribusi frekuensi, dan distribusi persentase adalah bentuk yang paling umum dari peringkasan data (Wibisono, 2000).

\section{Analisis Faktor}

Analisis faktor pada prinsipnya digunakan untuk mereduksi data, yaitu proses untuk meringkas sejumlah variabel menjadi sedikit dan menamakannya sebagai faktor.

\section{Kerangka Pemikiran}

Kerangka pemikiran dari penelitian ini tampak dalam Gambar 1.

\section{HASIL DAN PEMBAHASAN}

\section{Gambaran Umum Responden}

Responden penelitian adalah nasabah individu Bank Muamalat Indonesia dan Bank Syariah Mandiri kantor cabang Purwokerto. Distribusi responden tampak dalam Tabel 1.

Sebagian besar responden adalah laki-laki

Tabel 1. Profil Responden

\begin{tabular}{|c|c|c|c|c|}
\hline No. & Profil & Deskripsi & Respons & Persentase \\
\hline \multirow[t]{2}{*}{1.} & Jenis kelamin & Laki-laki & 68 & $56,67 \%$ \\
\hline & & Perempuan & 52 & $43,33 \%$ \\
\hline \multirow[t]{4}{*}{2.} & Usia & Kurang dari 20 tahun & 15 & $12,50 \%$ \\
\hline & & $21-35$ tahun & 87 & $72,50 \%$ \\
\hline & & $36-50$ tahun & 16 & $13,33 \%$ \\
\hline & & Lebih dari 50 tahun & 2 & $1,67 \%$ \\
\hline \multirow[t]{2}{*}{3.} & Agama & Islam & 120 & $100 \%$ \\
\hline & & Lainnya & 0 & $0 \%$ \\
\hline \multirow[t]{4}{*}{4.} & Pendapatan & Kurang dari Rp. 1.000 .000 & 70 & $58,33 \%$ \\
\hline & & Rp. 1.000 .000 - Rp. 3.000 .000 & 43 & 35,83 \\
\hline & & Rp. 3.000 .000 - Rp. 5.000 .000 & 5 & $4,17 \%$ \\
\hline & & Lebih dari Rp. 5.000 .000 & 2 & $1,16 \%$ \\
\hline \multirow[t]{6}{*}{5.} & Pekerjaan & Pegawai negeri & 11 & $9,17 \%$ \\
\hline & & Pegawai swasta & 45 & $37,50 \%$ \\
\hline & & Wiraswasta & 5 & $4,17 \%$ \\
\hline & & Pegawai BUMN & 0 & $0 \%$ \\
\hline & & Mahasiswa & 55 & $45,83 \%$ \\
\hline & & Lainnya & 4 & $3,33 \%$ \\
\hline \multirow[t]{3}{*}{6.} & Lama menabung & Kurang dari 1 tahun & 41 & $34,17 \%$ \\
\hline & di Bank syariah & 1 tahun - 2 tahun & 40 & $33,33 \%$ \\
\hline & & Lebih dari 2 tahun & 39 & $32,50 \%$ \\
\hline
\end{tabular}

Sumber: Data primer diolah 
dan berusia antara 21 sampai 35 tahun. Sedangkan berdasarkan agama semua responden mengaku beragama Islam. Dari jenis pekerjaan sebagian besar responden bank syariah di Purwokerto adalah mahasiswa serta pegawai swasta. Sementara dari segi penghasilan, mayoritas responden tergolong ke dalam masyarakat dengan pendapatan menengah. Hal ini sejalan dengan hasil Penelitian Potensi, Preferensi dan Perilaku Masyarakat Terhadap Bank Syariah di Jawa Tengah dan Daerah Istimewa Yogyakarta yang dilakukan oleh Bank Indonesia bekerjasama dengan Universitas Diponegoro (2000) serta hasil Penelitian di Jawa Barat yang dilakukan oleh Bank Indonesia dan Institut Pertanian Bogor (2000) menyatakan bahwa perbankan syariah banyak diminati oleh masyarakat dengan penghasilan menengah kebawah.

\section{Analisis Data}

Tabel 2 menunjukkan ranking faktor-faktor dalam kriteria seleksi berdasarkan mean. Hasil perhitungan mean dari faktor-faktor kriteria seleksi terhadap bank syariah menunjukkan bah- wa faktor keramahan personel bank merupakan faktor yang paling diperhitungkan konsumen untuk menabung di bank syariah. Hasil ini berbeda dengan hasil penelitian sebelumnya yang dilakukan oleh Gerrard dan Cunningham (1997), dimana dalam kriteria seleksi, faktor pelayanan cepat dan efisien serta kredibilitas bank merupakan faktor utama yang dipertimbangkan konsumen dalam memilih bank syariah.

\section{Analisis Faktor}

Untuk menentukan sekelompok variabel yang layak sebagai faktor digunakan kriteria berdasarkan nilai eigen value yang lebih besar atau sama dengan satu.

Dari hasil perhitungan didapatkan nilai KMO (Kaiser Mayer-Olkin) sebesar 0,799 dan uji Barletts 1374,812 dimana nilai KMO tersebut lebih besar dari 0,5 $(>0,5)$ pada taraf signifikansi 0,000. Maka dapat disimpulkan bahwa terdapat korelasi antara variabel-variabel tersebut. Dengan demikian maka model analisis faktor yang ada memenuhi syarat. Nilai total variance 68,103

Tabel 2. Perankingan Berdasarkan Hasil Mean

\begin{tabular}{lcc}
\hline Kriteria Seleksi & Mean & Ranking \\
\hline Keramahan Personel Bank & 8,42 & 1 \\
Reputasi atau image bank & 8,23 & 2 \\
Kredibilitas bank & 8,17 & 3 \\
Sambutan yang diberikan bank & 7,96 & 4 \\
Kredibilitas manajemen bank & 7,71 & 5 \\
Luasnya jangkauan pelayanan & 7,49 & 6 \\
Pelayanan cepat & 7,43 & 7 \\
Kenyamanan interior & 7,43 & 8 \\
Pelayanan efisien & 7,38 & 9 \\
Penyediaan pelayanan konsultasi keuangan & 7,35 & 10 \\
Istilah pembiayaan yang menarik & 7,13 & 11 \\
Biaya jasa yang rendah & 7,09 & 12 \\
Counter dalam bank yang menarik & 6,98 & 13 \\
Ketersediaan fasilitas pendukung & 6,84 & 14 \\
Tampilan luar bank & 6,83 & 15 \\
Bagi hasil yang tinggi & 6,75 & 16 \\
Biaya pinjaman yang rendah & 6,69 & 17 \\
Pengiklanan di media massa & 6,65 & 18 \\
Hak istimewa (Overdraft) bagi pemegang rekening & 6,56 & 19 \\
Tempat parkir yang luas & 6,18 & 20 \\
Lokasi dekat dengan tempat kerja & 5,99 & 21 \\
Lokasi dekat dengan tempat tinggal & 5,81 & 22 \\
Rekomendasi teman & 5,67 & 23 \\
Rekomendasi keluarga & 4,09 & 24 \\
\hline Sumber Data primer & &
\end{tabular}

Sumber: Data primer diolah 
persen menunjukan bahwa 68,103 persen variasi dari keseluruhan variabel dapat dijelaskan oleh seluruh persamaan yang terbentuk, lihat Tabel 3.

\section{Interpretasi Faktor}

Interpretasi faktor dapat dilakukan dengan mengelompokkan variabel-variabel berdasarkan faktor loading. Dari Tabel 3 dapat dilihat variabel-variabel yang tersebar pada 7 faktor dengan persentase total varian sebesar 68,103. Angka ini memperlihatkan bahwa penelitian ini mampu menjelaskan faktor-faktor yang menjadi pertimbangan konsumen dalam memilih bank syariah sebesar 68,103 persen.

Faktor 1 (Persepsi) merupakan faktor tertinggi yang menjadi pertimbangan konsumen

Tabel 3. Hasil Rotasi Faktor Menggunakan Rotasi Varimax

\begin{tabular}{|c|c|c|}
\hline Item dan Dimensi Kunci & Loading & Communalities \\
\hline \multicolumn{3}{|l|}{ Faktor 1 - Persepsi } \\
\hline 1. Reputasi atau image bank & 0,811 & 0,773 \\
\hline 2. Kredibilitas bank & 0,755 & 0,728 \\
\hline 3. Kredibilitas manajemen bank & 0,662 & 0,713 \\
\hline $\begin{array}{l}\text { 4. Luasnya jangkauan pelayanan } \\
\text { (Eigenvalue }=7,693 \text {; Variance }=32,056 \%)\end{array}$ & 0,594 & 0,531 \\
\hline \multicolumn{3}{|l|}{ Faktor 2 - Proses } \\
\hline 1. Pelayanan Cepat & 0,761 & 0,786 \\
\hline 2. Pelayanan Efisien & 0,751 & 0,804 \\
\hline $\begin{array}{l}\text { 3. Ketersediaan fasilitas pendukung } \\
(\text { Eigenvalue }=2,537 ; \text { Variance }=10,572 \%)\end{array}$ & 0,567 & 0,626 \\
\hline \multicolumn{3}{|l|}{ Faktor 3 - Bukti Fisik } \\
\hline 1. Tampilan luar bank & 0,737 & 0,665 \\
\hline 2. Kenyamanan interior & 0,620 & 0,703 \\
\hline 3. Counter dalam bank yang menarik & 0,601 & 0,716 \\
\hline 4. Tempat parkir yang luas & 0,565 & 0,557 \\
\hline $\begin{array}{l}\text { 5. Pengiklanan di media massa } \\
\text { (Eigenvalue }=1,446 ; \text { Variance }=6,024 \%)\end{array}$ & 0,553 & 0,600 \\
\hline \multicolumn{3}{|l|}{ Faktor 4 - Harga } \\
\hline 1. Biaya Pinjaman yang rendah & 0,811 & 0,718 \\
\hline 2. Istilah pembiayaan yang menarik & 0,626 & 0,518 \\
\hline 3. Biaya jasa yang rendah & 0,571 & 0,561 \\
\hline $\begin{array}{l}\text { 4. Bagi hasil yang tinggi } \\
\text { (Eigenvalue }=1,256 ; \text { Variance }=5,235 \% \text { ) }\end{array}$ & 0,533 & 0,580 \\
\hline \multicolumn{3}{|l|}{ Faktor 5 - Manusia } \\
\hline 1. Keramahan personel bank & 0,770 & 0,753 \\
\hline 2. Penyediaan pelayanan konsultasi keuangan & 0,692 & 0,748 \\
\hline $\begin{array}{l}\text { 3. Sambutan yang diberikan bank } \\
\text { (Eigenvalue }=1,224 ; \text { Variance }=5,099 \%)\end{array}$ & 0,638 & 0,737 \\
\hline \multicolumn{3}{|l|}{ Faktor 6 - Sosial } \\
\hline 1. Rekomendasi keluarga & 0,818 & 0,718 \\
\hline 2. Rekomendasi teman & 0,749 & 0,698 \\
\hline $\begin{array}{l}\text { 3. Hak istimewa (overdraft) bagi pemegang rekening } \\
\text { (Eigenvalue }=1,129 \text {; Variance }=4,705 \%)\end{array}$ & 0,493 & 0,516 \\
\hline \multicolumn{3}{|l|}{ Faktor 7 - Lokasi } \\
\hline 1. Lokasi dekat dengan tempat tinggal & 0,847 & 0,790 \\
\hline $\begin{array}{l}\text { 2. Lokasi dekat dengan tempat kerja } \\
(\text { Eigenvalue }=1,059 ; \text { Variance }=4,413 \%)\end{array}$ & 0,799 & 0,805 \\
\hline $\begin{array}{l}\text { Total Variance }=68,103 \% ; K M O=0,799 \\
\text { Determinant }=3,80 \mathrm{E}-006 \\
\text { Barletts Test Spherricty }=1374,812\end{array}$ & & \\
\hline
\end{tabular}


dalam memilih bank syariah karena memiliki eigen value sebesar 7,693 dan mampu menjelaskan 32,056 persen variasi dari seluruh variabel yang ada. Pentingnya faktor persepsi tidak lepas dari peran penting branding bagi perusahaan jasa, terutama perbankan. Karena dapat memudahkan konsumen dalam memahami jasa, dan menekan persepsi pelanggan terhadap resiko.

Faktor proses merupakan faktor kedua yang menjadi pertimbangan konsumen dalam memilih bank syariah karena memiliki eigen value sebesar 2,537 dan mampu menjelaskan keragaman total sebesar 10,572 persen. Variabel yang dominan dalam faktor proses adalah pelayanan cepat dan efisien. Pelayanan adalah suatu kegiatan atau urutan kegiatan yang terjadi dalam interaksi langsung antara seseorang dan orang lain atau mesin secara fisik, dan menyediakan kepuasan pelanggan.

Faktor bukti fisik merupakan faktor ketiga yang menjadi pertimbangan konsumen dalam memilih bank syariah karena memiliki eigen value sebesar 1,446 dan mampu menjelaskan keragaman total sebesar 6,024 persen. Karakteristik intangible pada jasa menyebabkan pelanggan potensial tidak bisa menilai suatu jasa sebelum mengonsumsinya. Oleh karena itu, faktor bukti fisik merupakan faktor yang penting dalam kriteria seleksi terhadap bank syariah.

Faktor harga merupakan faktor keempat yang menjadi pertimbangan konsumen dalam memilih bank syariah karena memiliki eigen value sebesar 1,256 dan mampu menjelaskan keragaman total sebesar 5,235 persen. Faktor harga yang terdiri dari biaya pinjaman dan biaya jasa yang rendah, istilah pembiayaan yang menarik, serta bagi hasil yang tinggi merupakan faktor yang cukup dipertimbangkan oleh konsumen.

Faktor orang merupakan faktor kelima yang menjadi pertimbangan konsumen dalam memilih bank syariah karena memiliki eigen value sebesar 1,224 dan mampu menjelaskan keragaman total sebesar 5,099 persen. Bagi sebagian besar jasa, orang merupakan unsur vital dalam bauran pemasaran. Jasa juga sangat bervariasi dan bergantung kepada komponen inputnya sejak dari personel kontak (karyawan perusahaan yang terlihat konsumen), proses produksinya, sampai kepada konsumen lain yang mungkin hadir di tempat jasa diproses (Yazid, 2001). Faktor orang ini sangat berkaitan dengan prinsip ekonomi syariah. Dalam hal pelaksanaannya, prinsip ekonomi syariah tercermin dalam nilai-nilai shiddiq, tabligh, amanah, dan fathanah yang secara umum menekankan aspek kompetensi atau profesionalisme dan sikap amanah (Bank Indonesia, 2002).

Faktor sosial merupakan faktor keenam yang menjadi pertimbangan konsumen dalam memilih bank syariah karena memiliki eigen value sebesar 1,129 dan mampu menjelaskan keragaman total sebesar 4,705 persen. Sikap konsumen memang bisa dibentuk atau diubah melalui kontak dengan orang-orang yang diteladani konsumen. Di dalam kelompok yang memiliki ikatan sosial yang tinggi, pengaruh pemimpin pendapat (opinion leader), sangat kuat dalam membentuk atau mengubah sikap anggota-anggotanya (Simamora, 2002). Oleh karena itu faktor sosial yang memiliki pengaruh yang cukup besar dalam kriteria seleksi terhadap bank syariah.

Faktor Lokasi merupakan faktor ketujuh yang menjadi pertimbangan konsumen dalam memilih bank syariah karena memiliki eigen value sebesar 1,059 dan mampu menjelaskan keragaman total sebesar 4,413 persen. Lokasi dapat mementukan keberhasilan maupun kegagalan usaha yang dilakukan perusahaan karena merupakan elemen penting dalam menentukan pendapatan yang diperoleh maupun biaya yang harus dikeluarkan perusahaan. Berbagai faktor perlu dipertimbangkan dalam menentukan lokasi perusahaan.

\section{Analisis Deskriptif}

Analisis deskriptif mengacu pada transformasi dari data-data mentah ke dalam suatu bentuk yang mudah dimengerti dan diterjemahkan. Bentuk yang digunakan dalam analisis ini adalah distribusi frekuensi.

\section{Pengetahuan Konsumen terhadap Bank Syariah}

Salah satu faktor yang cukup penting dalam mengkaji pengembangan bank syariah adalah melalui pengetahuan masyarakat terhadap keberadaan bank syariah. Dari hasil perhitungan 


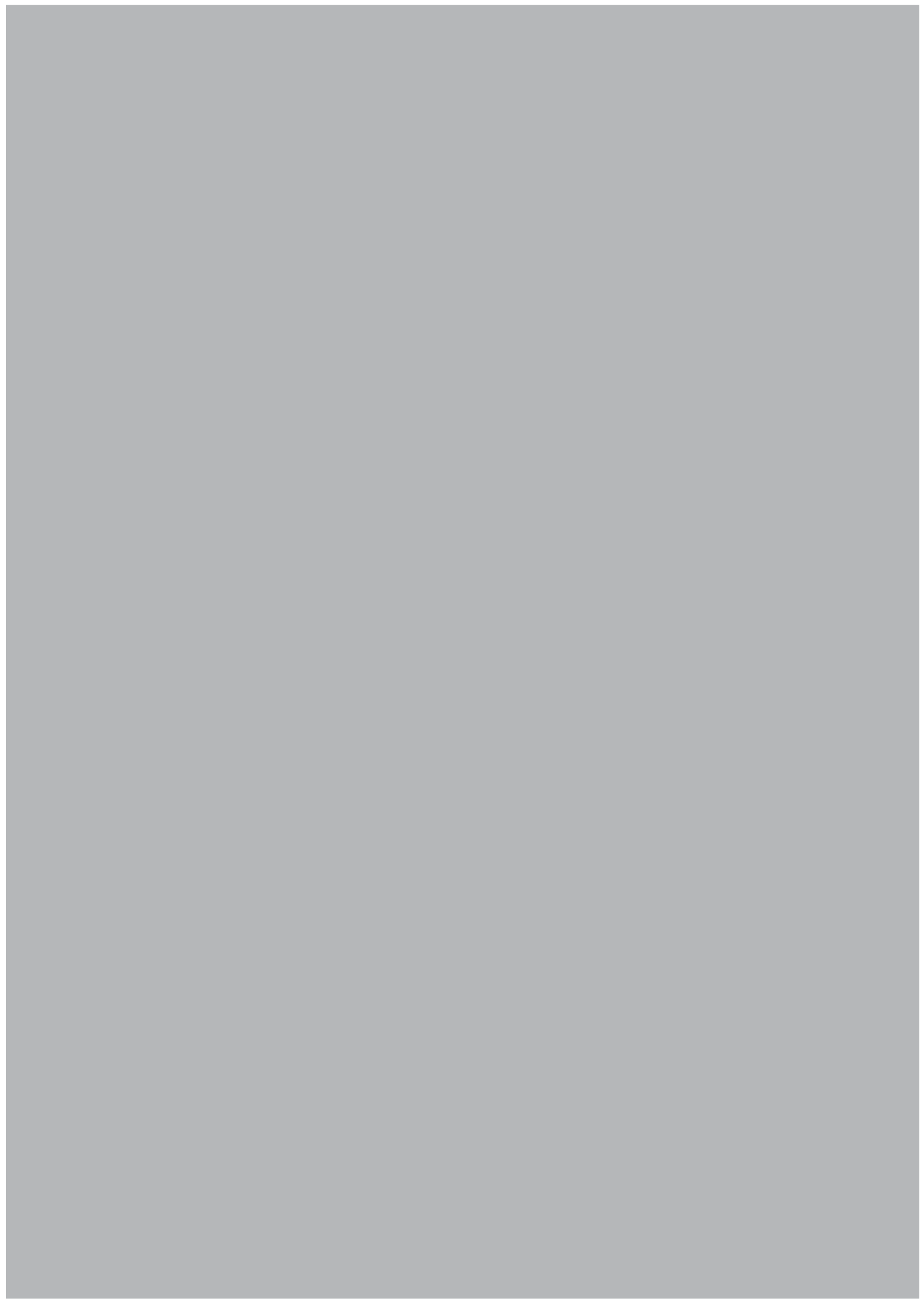


dak menghasilkan laba dalam beberapa tahun, yang dilakukan sebagian besar nasabah adalah tetap menabung di tempat yang sama atau bank syariah yang lain, karena menabung di bank yang bukan syariah sangat bertentangan dengan prinsip Islam. Hasil ini dapat diartikan bahwa sebanyak 95 responden atau 79,17 persen dari total responden merupakan konsumen yang loyal. Loyalitas tersebut ditunjukkan dengan sikap tetap menabung di bank syariah walaupun investasi dan tabungan di bank tersebut tidak menghasilkan laba. Hal ini juga menunjukkan bahwa konsumen menabung di bank syariah bukan hanya karena alasan keuntungan semata, tetapi juga karena alasan agama.

Pertanyaan keempat menunjukkan bahwa 56,67 persen atau sebanyak 68 responden menyatakan sangat setuju dengan pengabulan pinjaman tanpa bunga yang dilakukan oleh bank syariah merupakan salah satu bentuk kontribusi pihak bank untuk membantu masyarakat secara adil dan efisien. Menurut Muhammad (2002) dua fungsi utama bank syariah adalah mengumpulkan dana dan menyalurkan dana. Penyaluran dana yang dilakukan bank syariah adalah pemberian pembiayaan kepada debitur yang membutuhkan, baik untuk modal usaha maupun untuk konsumsi. Hal ini sesuai dengan salah satu target pencapaian pengembangan sistem perbankan syariah nasional yang terdapat pada cetak biru pengembangan perbankan syariah di Indonesia yaitu memiliki peran signifikan dalam sistem perekonomian nasional serta perbaikan kesejahteraan rakyat.

Pertanyaan kelima yang menanyakan apa yang dilakukan konsumen apabila mendapatkan sejumlah uang yang banyak secara tidak terduga. Ternyata sebanyak 37 responden atau sebesar 30,83 persen menyatakan akan membuka usaha atau proyek kecil yang bisa menghasilkan keuntungan. Selain itu, sebanyak 34 responden atau sebesar 28,33 persen menyatakan akan menyimpan sejumlah uang yang tidak diharapkan tersebut pada bank syariah yang beroperasi sesuai dengan sistem bagi hasil. Sedangkan sebanyak 44 responden atau sebesar 36,67 persen menyatakan akan melakukan kombinasi dari jawaban diatas, yaitu membuka usaha dan menyimpan sebagian uangnya ke bank syariah.

Pada pertanyaan terakhir, sebanyak 44 responden atau 36,67 persen menyatakan setuju dengan pernyataan bahwa penetapan bunga diawal pinjaman untuk proyek investasi, konstruksi rumah, pembelian mobil dan pembiayaan dihapuskan, seperti pada prinsip bagi hasil antara bank dan peminjam, lebih menguntungkan peminjam. Hasil penelitian ini juga sama dengan hasil penelitian yang dilakukan oleh Gerrard dan Cunningham (1997) bahwa sebagian besar responden atau sebanyak 55,2 persen menyatakan setuju dengan pernyataan tersebut. Berdasarkan hasil dari pertanyaan terbuka yang ada dalam kuesioner, sebagian besar alasan responden adalah karena sesuai dengan prinsip agama, dan tidak ada riba.

\section{SIMPULAN}

Berdasarkan hasil analisis serta interpretasi dari hasil penelitian mengenai kriteria seleksi, pengetahuan, dan sikap konsumen terhadap bank syariah, maka dapat disimpulkan bahwa ada tujuh faktor yang menjadi kriteria seleksi konsumen terhadap bank syariah di Purwokerto antara lain: faktor persepsi, faktor proses, faktor bukti fisik, faktor harga, faktor orang, faktor sosial, faktor lokasi. Faktor yang paling dominan dipertimbangkan konsumen dalam memilih bank syariah adalah faktor persepsi dengan variance sebesar 32,056 persen yang berarti dapat menjelaskan 32,056 persen dari variasi yang ada. Untuk perankingan kriteria seleksi berdasarkan nilai mean, faktor yang paling diperhitungkan adalah faktor keramahan personel bank dengan nilai mean 8,42.

Pengetahuan konsumen terhadap bank syariah masih terbatas, sebagian besar responden hanya mengetahui tentang riba dan syariah. Sedangkan istilah-istilah dalam perbankan syariah seperti ijarah, mudharabah, musyarakah, dan murabahah masih belum diketahui dan dimengerti oleh konsumen. Alasan utama konsumen menabung di bank syariah adalah karena kombinasi dari alasan agama dan alasan keuntungan. Sebagian besar konsumen sangat setuju apabila bank syariah membuka cabang di seluruh Indonesia, banyak konsumen yang 
akan menggunakan jasa bank tersebut. Apabila ada suatu kasus, bank syariah memberitahukan bahwa investasi dan tabungan tidak menghasilkan laba dalam beberapa tahun, yang dilakukan sebagian besar nasabah adalah tetap menabung di tempat yang sama atau bank syariah yang lain, karena menabung di bank yang bukan syariah sangat bertentangan dengan prinsip islam. Konsumen sangat setuju dengan pengabulan pinjaman tanpa bunga yang dilakukan oleh bank syariah merupakan salah satu bentuk kontribusi pihak bank untuk membantu masyarakat secara adil dan efisien. Apabila konsumen mendapatkan sejumlah uang yang banyak secara tidak terduga, sebagian besar menyatakan akan membuka usaha atau proyek kecil yang bisa menghasilkan keuntungan dan menyimpan sejumlah uang pada bank syariah yang beroperasi sesuai dengan sistem bagi hasil. Sebagian besar konsumen setuju dengan pernyataan bahwa penetapan bunga di awal pinjaman untuk proyek investasi, konstruksi rumah, pembelian mobil dan pembiayaan dihapuskan, seperti pada prinsip bagi hasil antara bank dan peminjam, lebih menguntungkan peminjam.

Ucapan terima kasih. Peneliti menyampaikan terimakasih kepada Ana Mariana atas bantuannya dalam pelaksanaan survei.

\section{DAFTAR PUSTAKA}

Al-Sultan, W. 1999. Financial Characteristics of Interest-free Banks and Conventional Banks, Wolongong Australia: University of Wolongong.

Antonio, Muhammad Syafi'i. 2001. Bank Syariah Dari Teori ke Praktek. Jakarta: Gema Insani Press.

Bank Indonesia. 2000. Potensi, Preferensi dan Perilaku Masyarakat Terhadap Bank Syariah di Jawa Tengah.

http://www.bi.go.id/web/id/Riset+Sur vey+Dan+Publikasi/Riset/Perbankan+Sy ariah/BPSESJatengindonesia.htm.

Bank Indonesia. 2000. Potensi, Preferensi dan Perilaku Masyarakat terhadap Bank Syariah di Jawa Timur.
http://www.bi.go.id/web/id/Riset+Sur vey+Dan+Publikasi/Riset/Perbankan+Sy ariah/BPSESJatimindonesia.htm.

Bank Indonesia. 2000. Potensi, Preferensi dan Perilaku Masyarakat terhadap Bank Syariah di Jawa Barat.

http://www.bi.go.id/web/id/Riset+Sur vey+Dan+Publikasi/Riset/Perbankan+Sy ariah/BPSESJabarindonesia.htm.

Bank Indonesia. 2002. Cetak Biru Pengembangan Perbankan Syariah Indonesia.

http://www.bi.go.id

Bley, J., Kuehn, K. 2004. Conventional versus Islamic finance: student knowledge and perception in the United Arab Emirates. International Journal of Islamic Financial Services, Vol. 5 No.4, pp.17-30.

Engel, James F, Blackwell, Roger D dan Miniard, Paul W. 1992. Perilaku Konsumen. Binarupa Aksara: Jakarta.

Erol, C and El-Bdour R. 1989. Attitudes, Behaviour and Patronage Factors of Bank Customers Towards Islamic Banks. International Journal of Bank Marketing.

Erol, C, Kaynak E and El-Bdour. 1990. Conventional and Islamic Bank: Patronage Behaviour of Jordanian Customers. International Journal of Bank Marketing.

Gait, A and Worthington C. 2007. An Empirical Survey of Individual Consumer, Business Firm and Financial Institution Attitudes towards Islamic Methods of Finance. Faculty of Commerce papers: University of Wollongong.

Gerrard, P and Cunningham J. 1997. Islamic Banking: A Study in Singapore. International Journal of Bank Marketing.

Haron, S, Ahmad N and Planisek S. 1994. Bank Patronage Factors of Muslim and Non Muslim Customers. International Journal of Bank Marketing.

Kotler, Philiph. 1998. Manajemen Pemasaran Analisis, Perencanaan, Implementasi, dan Pengendalian. Jakarta: Erlangga.

Malhotra, Naresh K. 2005. Riset Pemasaran, Pen- 
dekatan Terapan. Jakarta: Indeks.

Metawa, S.A., Almossawi, M. 1998. Banking Behaviour of Islamic Bank Customers: Perspectives and Implications, International Journal of Bank Marketing, Vol. 16 No.7, pp.299-313.

Metwally, M. 2002. The Impact of Demographic Factors on Consumers' Selection of A Particular Bank Within A Dual Banking System: A Case Study, Journal of International Marketing and Marketing Research, Vol. 27 No.1, pp.35-44.

Mowen, John C, Michael Minor. 2002. Perilaku Konsumen, Jilid 1. Jakarta: Erlangga.

Muhammad. 2002. Manajemen Bank Syariah. Yogyakarta: UPP AMP YKPN.

Omer, H.S.H. 1992. The Implications of Islamic beliefs and Practice on the Islamic Financial Institutions in the UK: Case Study of Albaraka International Bank UK, Economics Department. Loughborough University, Loughborough, unpublished $\mathrm{PhD}$ thesis.

Prasetijo, Ristiyanti, dan John J.O.I Ihalauw. 2005. Perilaku Konsumen. Yogyakarta: Penerbit Andi.

Sekaran, Uma. 2006. Research Methods for Busi- ness. Jakarta: Salemba Empat.

Setiadi, Nugroho J. 2003. Perilaku konsumen. Jakarta: Prenada Media.

Simamora, Bilson. 2004. Panduan Riset Perilaku Konsumen. Jakarta: PT Gramedia Pustaka Utama.

Suliyanto. 2005. Analisis Data dalam Aplikasi Pemasaran. Bogor: Ghalia Indonesia.

Sumarwan, Ujang. 2004. Perilaku Konsumen Teori dan Penerapannya dalam Pemasaran. Bogor: Penerbit Ghalia Indonesia.

Supranto, J. 1997. Pengukuran Tingkat Kepuasan Pelanggan untuk Menaikkan Pangsa Pasar. Jakarta: PT Rineka Cipta.

Tjiptono, Fandy. 2000. Pemasaran Jasa. Malang: Bayumedia Publishing.

Umar, Husein. 2003. Riset Pemasaran dan Perilaku Konsumen. Jakarta: PT Gramedia Pustaka Utama.

Wibisono, Dermawan. 2000. Riset Bisnis, Seri Komunikasi Profesional. Yogyakarta: BPFE

Yazid. 2001. Pemasaran Jasa; Konsep dan Implementasi. Yogyakarta: Ekonisia. 